\title{
The Nature of Sinitic Lexicon in Bazaar Malay and Baba Malay in Singapore
}

\author{
Khin Khin Aye
}

$1 \quad$ Introduction

Voluntary or involuntary, human migration is fundamental to Asian history and to the world in general. Wherever people migrate, they introduce their languages, cultures, religions and beliefs to the host communities. Chinese emigration to other countries started as early as 1000 CE. From the midnineteenth century, their migration to other countries has resulted in more than 30 million so-called "Overseas Chinese", who live outside mainland China and include over 20 million people in Southeast Asia (Lockard 2013), affecting the world's demographics, economy, culture, and language, just to name a few. In terms of population, according to Hay (2008), ethnic Chinese range between $0.8 \%$ and $76 \%$ of the population of each Southeast Asian nation. These numbers do not take into consideration partially assimilated Chinese in these communities. Ethnic Chinese make up 34\% of the population (6 million) in Malaysia and $76 \%$ (2 million) in Singapore, the majority of whom are descendants of Hokkien speakers present since the early days of Singapore. Economic dominance of the Chinese is felt in countries such as Malaysia, Singapore, Thailand, and Indonesia. As pointed out by Hays (2008), the economies are mostly controlled by rich Chinese in these countries.

Migration also set the stage for immigrant Chinese and host communities, who spoke a range of different languages, to communicate and interact. This required the people involved to tap into the full repertoire of languages at their disposal. As noted by the mainland Chinese novelist Wang Anyi 王安憶 in the context of Singapore and Malaysia, but equally valid for other Southeast Asian countries, "Hua people must endure speaking the language of another ethnic group" (Ng 2013: 84). Explicit or implicit lexical borrowing between the languages involved in such processes is one of the most common consequences of contact, and has been observed in all world languages (Hoffer 2005). The Loanword Typology Project, coordinated by Haspelmath and Tadmor between 2004 and 2008, looked at loanwords in 41 world languages. Based on these findings, Tadmor (2009) ranks English among the "high borrowers" with 40\% 
of its total words identified as loanwords. Mandarin hit the study's bottom of "low borrowers" with only $1.2 \%$. Evidence furthermore shows that loanwords from Chinese varieties have been found, for example, in Indonesian and Malay. Jones (2009: 9) identifies the word tahu 豆腐 'bean curd' as the region's earliest Hokkien loanword, found in a tenth-century Old Javanese inscription. The absence of similar evidence in Old Malay inscriptions led him to assert that Chinese loanwords entered the Malay language only during the Qing Dynasty (1664-1912). Scholars like Jones (2009), Pou \& Jenner (1973), and Egerod (1959) have investigated Chinese loanwords in, respectively, Malay, Khmer, and Thai. Yet compared to the large body of scholarship on loanwords from English in other world languages or foreign loanwords into English, for example Durkin (2014), studies on Sinitic loanwords into other languages have been relatively limited.

Another migration-related outcome is the emergence of lingua francas: contact languages used for communication among people of diverse backgrounds. Two cases in point are Bazaar Malay and Baba Malay, both of which are Malay-based contact varieties with different sociolinguistic statuses. The former is a Malay-lexified lingua franca used for several centuries in the multilingual trade ports of Southeast Asia. It existed in Singapore since the early days of its modern history, beginning in 1819. As pointed out by Collins (1984), it was nobody's first language, yet it was the only form of Malay spoken by elderly non-Malay Singaporeans and Malaysians. Singapore Bazaar Malay was used by Malays to non-Malays, non-Malays to Malays and Baba Chinese, among non-Malays when they did not have any common language, and among Chinese, Malays, or Indians who spoke mutually comprehensible languages (Aye 2006: 24). Baba Malay, on the other hand, is the first language of the Peranakan Chinese community in Singapore and Malaysia. Peranakan Chinese are Straits-born Chinese and their descendants, who have developed a rich creolized culture, language, and literature. This was the community of Chinese in Singapore and Malaysia that pioneered romanized Baba Malay publications, which were translated mostly from Chinese and to a lesser extent from English literature. Researchers such as Tan (1993: 40) and Ansaldo and Matthews (1999: 45) zero in on the connection between these two Malay-based varieties, noting their shared Chinese input and the possible contribution of Batavia Bazaar Malay to the formation of Baba Malay (cf. Pakir 1986). Pakir (1986) and Aye (2006), among others, shed light on Sinitic influence on Singapore Baba Malay and Bazaar Malay, though their studies focus more on describing linguistic features as a whole while also considering their socio-cultural and sociolinguistic contexts. The historical and demographic accounts of modern Singapore 
analysed in these studies point to a shared linguistic ecology in which both varieties emerged, featuring Hokkien as their major substrate.

As a Myanmar Chinese with Fuzhou as my first language, married into a Hokkien family in Myanmar, I have long been motivated to investigate Sinitic influences on the languages and cultures of their host communities. My linguistic and academic background started to converge during my postgraduate diploma course, when I started to study and write about Hokkien kinship terms and code-switching in a Sino-Myanmar family. Against the backdrop of limited scholarship on Sinitic loanwords (except the publications mentioned previously) measured against the ubiquity of Chinese people in Southeast Asia, this chapter investigates the nature of the Hokkien lexicon in Bazaar Malay and Baba Malay used in Singapore. The Bazaar Malay data have been collected from ten consultants between 2002 and 2004, whereas the Baba Malay data were acquired through a textual analysis of the novel Si Hitam Yang Chantek, the Baba Malay version of Anna Sewell's (1797-1884) famous Black Beauty. It was one of very few translations into Baba Malay not based on a Chinese original. Published by Singapore Methodist Publishing House in 1913 and translated by Goh Hood Keng 吳佛經, the book was intended for Christian Peranakan Chinese (Proudfoot 1993: 259). It was selected as the use of uncommon Hokkien cultural terms in this book was minimal compared to Baba Malay publications translated from Chinese stories (Shellabear 1919: 383 ). As such, the idiom in $S i$ Hitam Yang Chantek is closer to the spoken language of that period.

It is well-known in the field of Pidgin and Creole Studies that substrate languages and their speakers are generally stigmatized (Bao 2003). This chapter argues that extralinguistic factors - the numerical dominance of Hokkien speakers in the history of Singapore's demographics and their spread in all walks of life - overruled this stereotype and facilitated the adoption of Hokkien lexicon into these Malay varieties. Differences in their sociolinguistic functions in Malaysia and Singapore have determined the degree of borrowing into both varieties.

According to Wang (1991), Chinese emigration over the last two centuries features four major models with distinctive professions, geographical origins, distributions, and temporal dimensions: (1) the Huashang 華商 'Chinese traders', especially in Southeast Asia before $185^{\circ}$, mainly consisting of male traders who later intermarried with the local communities once settled down; (2) the 
Huagong 華工 'Chinese coolies', consisting of male peasants, especially to North America and Australia between 1840 os and 1920s as workers involved in mining, railway building, and agriculture sectors; (3) the Huaqiao 華僑 'Overseas Chinese', especially since 1911, by well educated professionals who were vital to the Chinese education of the descendants of earlier immigrants in Southeast Asia; and (4) the Huayi 華裔 'people of Chinese descent', that is, descendants of Chinese migrants from one foreign country (e.g. in Southeast Asia) to another (e.g. in Western Europe), especially since the 195os, when their participation in economic sectors was curtailed (Pan 1990: 226).

Chinese emigration to Singapore and West Malaysia (formerly known as Malaya) reflects three main patterns of migration: (1) the Huashang migration, which led to the birth of the Peranakan or Straits-born Chinese community whose first language was Baba Malay; (2) the Huagong migration that led to later waves of Chinese migration into Singapore since 1824; and (3) the Huaqiao migration which between the 1920 and 195 os played a pivotal role in teaching Chinese to Chinese-descended Southeast Asians who had already settled down in the local communities (Pan 1990: 206; Poston and Luo 2007). Chinese in Southeast Asia came predominantly from the southern Chinese coastal provinces of Fujian and Guangdong and some from Hainan in southern China (Freedman 196o: 26; Hay 2008; Pyau Ling 1912: 75). Chinese people, speaking a number of Sinitic varieties, mostly live in Southeast Asia's urban areas, including a number of "Chinatowns", while others live in the rural areas (cf. Hay 2008; Poston and Wong 2016: 367 ).

Singapore as a multi-ethnic and multicultural island state is unique in a broader Southeast Asian context for having English (the language of business and administration), Mandarin, Malay (the National Language), and Tamil as its four official languages. Most Singaporeans are bilingual (or multilingual) and speak their "mother tongue" and English with varying degrees of fluency. According to Population Trends, out of a total population of 3,965,796 in 2017, the ethnic Chinese made up 74.3\%, Malays (including those of Indonesian descent) 13.4\%, Indians of different ethnic or linguistic groups $9 \%$, and others - which include Eurasians and Europeans - 3.2\%. In this linguistic ecology, Singapore Bazaar Malay (the lingua franca of this multilingual community) and Baba Malay (the first language of the Straits-born Chinese) historically existed together with the languages spoken by these four major groups. Given the massive language shift in Singapore to English, both Malay varieties now suffer the same fate of language endangerment. The position of the nation's official Malay variety, conversely, remains stable, although it has become somewhat uncommon outside the nation's Malay community and government announcements. 
Bazaar Malay, also known as "Pasar Malay", "Pasar Melayu" or "Melayu Pasar", served for several centuries as a lingua franca in Southeast Asia's major commercial centres, including for nearly two centuries in Singapore (Collins 1987; van Minde 1997: 8; Paauw 2008). ${ }^{1}$ The earliest trading contacts with India and China (Baxter 1985: 14; Prentice 1992: 374) and the associated commercial networks ultimately gave rise to several trade centres, such as Malacca on the southwest coast of the Malay Peninsula (before 1511) and later Singapore (since 1819). Business transactions in these trade centres were highly diverse, involving people from different origins, such as Chinese, Gujaratis, South Indians, Javanese, and Malays (Hall 1985: 86). This resulted in the development of Bazaar Malay to meet the communicative needs of those involved in the business transactions of these marketplaces. Its lexifier language was Malay, which was conventional given the latter's geographical distribution along the Straits of Malacca and its significant role in the region's administration, religion, culture, and commerce. Bazaar Malay is no one's first language, and at the time when I collected data in Singapore, its speakers (fewer than 1,00o) mostly belonged to the older generations and some middle-aged workers whose daily routine required them to deal with elderly Singaporeans who did not speak English. Its role as the lingua franca had been replaced by English due to education policies and language campaigns launched in Singapore and resulting in a massive language shift (Poedjosoedarmo 1997).

Baba Malay, conversely, developed out of intermarriages between early Chinese immigrants and local speakers of Malay. It became the first language of the Peranakan or Straits-born Chinese and their descendants. ${ }^{2}$ The forebears of the Baba Chinese were early Hokkien-speaking immigrants from Fujian who migrated to Malacca around the fifteenth century, long before the establishment of the British Straits Settlements (Purcell 1948; Vaughan 1971; Ansaldo \& Matthew 1999: 39). Their Malay-lexified creole was a hybrid between Malay and Hokkien, which was comprehensible to native Malay speakers (Pakir 1986; Thurgood 1998; Lee 2014). These Straits-born Chinese also became pioneers in learning - and shifting to - English. Their knowledge of English, Hokkien, and Malay enabled them to act as go-betweens for business transactions between European firms and local trade centres (Platt and Weber 1980: 3). Unlike Bazaar Malay, Baba Malay had a well-established speech

1 Note that not all researchers may refer to precisely the same variety. As discussed in Paauw (2008: 9), the term "Bazaar Malay" is used to refer to two different things: (1) the contact language that emerged in the multi-ethnic West Malaysia (Adelaar 1991; Bakker 2003, 2004), and (2) the vehicular trade language that spread throughout the Indonesian islands (Adelaar and Prentice 1996).

2 The men of this community are known as babas and women as nyonyas. 
community with a rich culture, language, and literature. The hybrid nature of this community (Chinese, Malay, and English) is reflected in their dress, unique architectural style, culinary skills, and mixed language and literature. The uniqueness of the Baba Malay language, as noted by previous researchers, includes the use of (Hokkien) Chinese words and expressions for specific items of clothing, culture, cooking, daily life, etc. Its phonology and morphosyntactic properties that differ from other Malay dialects have received academic attention (Pakir 1986; Tan 1998, 2004; Lee 2014). Researchers such as Shellabear (1913), Png (1963), and Gwee (2006) have conducted Baba Malay lexical studies, while Gwee (1993) added phrases, sayings, and expressions. The Straits-born Chinese were the first Chinese in the Malay Peninsula to use a romanized form of their spoken language in their literary publications. While there is an ongoing debate on whether to classify Baba Malay as a creole (Lee 2014, for example) or a Malay dialect (Pakir 1986; Tan 1998), this chapter approaches it as a Malay-based contact language. Like Bazaar Malay, Baba Malay is fast disappearing in Singapore and Malaysia, with the increasingly extensive use of English among the younger generation. According to Lee (2014: vii), it has less than 1000 speakers in Singapore and Malacca (Malaysia) respectively.

Since the establishment of modern Singapore in 1819, its population has been strikingly multiracial, multicultural, and multilingual. The island's free trade, job openings, law and orderliness attracted immigrants from diverse ethnolinguistic and cultural backgrounds. This in turn offered an excellent breeding ground for contact varieties such as Bazaar Malay to evolve. Languages spoken by immigrants can be considered as input languages in the development of Bazaar Malay. They include various languages spoken by Malay, Chinese, Indian, Eurasian, and European people. In the development of Baba Malay, Malay and Chinese varieties, specifically Hokkien, played the most important role. Other Chinese immigrants were speakers of Teochew or other Min varieties, Cantonese, Hainanese, and Hakka. As the name suggests, Bazaar Malay has Malay as its lexifier and other languages as substrate elements. Baba Malay, on the other hand, has Malay as lexifier and Hokkien as its sole substrate. Unlike other parts of the region, where Chinese are a minority group, in Singapore the ethnic Chinese have since the 1840 os predominated in terms of population and in most sectors of the economy, as trade was largely in the hands of Chinese businessmen and Europeans (Platt and Weber 1980: 3). ${ }^{3}$

3 Chinese makes up $50 \%$ of the total population in $1840,61.2 \%$ in $1860,67.1 \%$ in $1891,72.4 \%$ in 1911, 75.1 in 1931, 76.9\% in 1957 and 1980, 76.8\% in 2000 (Aye 2013: 87; Bao 2001: 281; Population 2000 Census). 
Furthermore, Chinese immigrants (excluding the Straits-born Chinese) engaged in all sorts of non-commercial activities (Tarling 1992: 10). As mentioned previously, Hokkien speakers constitute the majority of ethnic Chinese in Singapore and Hokkien has been used for Chinese inter-group communication; while the island's other Sinitic varieties exhibit a shared core grammar, most are mutually unintelligible (Kuo 1976: 11; Bao 2005). The economic and social dominance of Hokkien speakers helps us to explain the status of Hokkien as the major substrate language of Bazaar Malay and Baba Malay. This chapter's focus on the nature of Hokkien borrowing is likely to also contribute to a better understanding of the unique features of Singapore English and Malaysian English, although they fall outside its scope. All these varieties (Bazaar Malay, Baba Malay, Singapore English, and Malaysian English) have developed in roughly the same linguistic ecology and their typological similarities attest to this shared history.

Theoretical Framework and Methodology

As I will argue in this section, the theories of borrowing and relexification described in the work of Claire Lefebvre can best explain the existence of Hokkien lexicon in Baba Malay and Bazaar Malay. Both processes are at play whenever speakers of different languages are in contact. Information on borrowing and relexification is provided below, followed by a brief note on my research methodology.

\subsection{Borrowing}

Borrowing is the linguistic strategy adopted by speakers to discuss new entities or concepts in another language. It is a discernible outcome of contact with people coming from diverse linguistic, cultural, and religious backgrounds. According to Hockett (1997, cf. Hoffer 2005), four borrowing options are available to the speakers of a language:

1. Loanwords: the adoption of words from a donor language, integrated into the borrowing language's grammatical system

2. Loan shift: attributing native words with new meanings

3. Loan translation or calque: the lexification of words in the borrowing language with syntactic and sematic properties from the donor language

4. Loan blend: the use of a combination of a loanword and a native word My analysis of Bazaar Malay and Baba Malay data suggests that all four options of borrowing can be observed in these varieties, though the quantity of each option differs. More details are provided and discussed in sections 4 and 5 . 


\subsection{Relexification}

In order to satisfactorily explain the nature of Hokkien lexicon in the two Malay varieties, I use the concept of relexification as a mental process, as proposed by Lefevre (1998), in tandem with two constraints put forward by Bao (2005). According to Bao (2015: 15) and Aye (2006: 194), new lexical entries in contact languages are adopted as a result of collaborative contributions from a superstrate or lexifier language and one or more substrate languages.

Relexification was first defined by Muysken (1981: 61). According to Lefevre (1998: 16), this process constructs new lexical entries in emerging contact languages in two phases: (i) copying the substrate lexicon, and (ii) replacing the phonological forms of substrate words with those from the lexifier language, which is termed "relabelling" (Lefebvre \& Lumsden 1994). According to Lefebvre (1998: 17), while all lexical categories can be copied, relabelling is semantically determined. In other words, this process takes place on the condition that there is an overlap between the semantics of the lexical item in the substrate and in the lexifier. The outcome of this process is a new lexical entry in the lexifier language's phonological form, though with the substrate language's semantic and syntactic properties.

Given the failure of this relexification process to yield some expected Chinese aspectual categories in Singapore English, Bao (2005) proposes two constraints to relexification - "system transfer" and "lexifier filter" - and identifies specific and interdependent roles played by the substrate and the lexifier language. A system transfer requires the compulsory transfer of the substrate's entire grammatical subsystem, while a lexical filter only allows for the transfer of the system which complies with the lexifier's surface structure requirements. In the discussion in section 5.2 on loan translations, we will see how this is relevant for the Hokkien-influenced Malay varieties studied here.

\subsection{Methodology}

To identify Hokkien loanwords in the two contact varieties, I started by analysing Bazaar Malay data collected from ten consultants: four Chinese, four Indians, one Boyanese, and one Malay. I met most of them between 2002 and 2005 in the Kolam Ayer Community Centre in the Geylang Bahru area of Singapore. Closer socialization among the older residents of different races in this area - along with the somewhat higher concentration of Malays, Indians, and other minority groups ${ }^{4}$ - may have caused these people to use Bazaar Malay as a communicative bridge within this community, despite its declining

4 The population ratio of the Kolam Ayer Constituency at that time was: Chinese $77.81 \%$, Malays $10.18 \%$, Indians $10.84 \%$, and others $1.17 \%$. 
use at that time. Most of them were born in Singapore and the rest had been living in Singapore for more than thirty years. The most salient characteristic of these consultants was that they had picked up Malay through informal acquisition. This was even the case with those who had learnt Malay formally, as they only learnt very basic vocabulary, although the duration of their education ranged from one to three years. Bearing in mind that triangulation is vital for valid fieldwork findings, data on my consultants' "relaxed", "natural" usage were collected by means of (i) survey questionnaires which I asked them personally, (ii) direct elicitation via a Translation Test, (iii) indirect elicitation through different means, and (iv) other strategies whenever appropriate (see Gil 2001: 121; Mithun 2001: 35; Milroy and Gordon 2003: 58). ${ }^{5}$

For Baba Malay, I looked at written rather than elicited data. According to Yoong \& Zainab (2002: 1), in order to accommodate the reading needs of the Baba community and their desire to have a written language, newspapers, poems, novels, magazines, and translated Chinese and English stories were published between the late 188 os and 1950 in romanized Baba Malay. Some examples of newspapers include the Straits Chinese Herald (Surat Khabar Peranakan) and Bintang Timor from 1894 and Khabar Slalu (Daily News) from 1924. In 1930, the first Baba Malay weekly, Bintang Pranakan, was published in romanized Malay. Yoong and Zainab (2002) found 68 titles of translated Baba Malay literature from Chinese stories between 1889 and $195^{\circ} .{ }^{6}$ One of the most famous examples of these works is Sam Kok 三國 (1892-96) translated from Luo Guanzhong's 羅貫中 Romance of the Three Kingdoms by Chan Kim Boon 曾錦文 (1851-1920). Ian Proudfoot's list of early Malay printed books until 1920 contains 16 entries of books intended for Christian readers, published by the American Mission Press and Methodist Publishing Press in Singapore. Among them we find Baba Malay translations of English novels, such as Kmnangan Miriam Kristofer (The Victory of Miriam Christopher by H.R. Calkins) translated by Mrs. J.M. Hoover (Proudfoot 1993: 306).

5 As my consultants were elderly Singaporeans, I raised questions close to their heart to grab their attention and trigger their reaction. These included questions about a popular lottery (toto) and childhood experiences in the case of a male consultant and about former colleagues in school and raising children in the case of a female consultant. Doing so guaranteed their emotional involvement and I managed to get a lot of spontaneous speech data. I also joined some of the activities of my consultants, including playing gate ball with a recorder hanging around my neck, and chatted informally with this entire group of senior citizens.

618 works between 1889 and 1909; 10 between 1910 and 1919; 39 between 1935 and 1939; and 1 in 195 . 
For this chapter, I have chosen Si Hitam Yang Chantek, which was translated by the aforementioned Goh Hood Keng and published by Methodist Publishing House in 1913 (Proudfoot 1993: 681). The book has 298 pages and consists of five parts divided into 45 chapters. The English original, The Black Beauty, was written by Anna Sewell. This first-person narrative is the autobiography of a horse named "Black Beauty". Using Antconc concordance software, I have conducted a textual analysis of the novel in 2005 and 2006, inspired by Pakir (1986) and subsequently filtered through the data of Lee (2014). ${ }^{7}$

\section{The Nature of Hokkien Lexicon in Bazaar Malay and Baba Malay}

While the majority of the lexicon of Bazaar Malay and Baba Malay is Malayderived, the influence of its Hokkien substrate is evident in both languages, although its pervasiveness differs across these varieties, in line with their different sociolinguistic statuses in Singapore.

Out of 1073 words in the glossary of Baba Malay provided by Lee (2014), Hokkien loanwords make up $15.56 \%$ ( 167 words / expressions), followed in quantity by some English loanwords. A total of 219 Hokkien words were identified by Pakir (1986: 116) in her Baba Malay data. These are categorized into 12 categories, only four of which were found in Bazaar Malay. These four include:

1) Terms of address, including kinship terms and personal pronouns,

2) Temporal expressions,

3) Business terms, and

4) Culinary terms.

In what follows, these different categories of Hokkien lexicon in Bazaar Malay and Baba Malay are described in detail, paying particular attention to kinship terms and personal pronouns.

\subsection{Kinship Terms}

The Hokkien lexical substrate in the use of terms of address in Bazaar Malay and Baba Malay has frequently been mentioned in the literature on contact linguistics and Malay linguistics (Baxter 1985; Pakir 1984; Holm 1989: 578-79; Adelaar \& Prentice 1996: 675; among many others). In Baba Malay, Pakir (1986: 107) lists Hokkien kinship terms in use among elderly Baba Chinese, who tend to have

7 Professor Bao Ziming kindly allowed me to use these data which I collected and analysed when working as a student research assistant at the Department of English Language and Literature, National University of Singapore between 2005 and 2006. 
a stronger sense of kinship and familial hierarchy. Out of the 72 kinship terms in Baba Malay provided by Lee (2014: 401-2), 55 (71.4\%) are Hokkien-derived, including gong 公 or gong gong 'grandfather', chau 'elder sister's husband,', etc. and the remaining 17 are from Malay. In the novel Si Hitam Yang Cantik, the use of the Hokkien word ngkong 'grandpa' 俺公 is found 18 times and tachi 大 姐 'elder sister' three times. Consider the following example from Chapter 4:

1) Saya banyak terima kasih kerana lu punya baik
ISG many accept love because 2 SG punya
kepada tachi
to saya.

It is not surprising to find a much smaller usage of such terms in Bazaar Malay, as this is a variety not just belonging to ethnic Chinese (in contrast to Baba Malay). Yet even Bazaar Malay speakers have been observed to use the appropriate kinship terms from Malay, Tamil, Hokkien - such as angso 俺嫂 'sister-in-law' to address a Chinese female colleague - and English (uncle and aunty) to show respect, intimacy, and friendliness among interlocutors (see also Collins 1987: 164).

\subsection{Personal Pronouns}

In both Bazaar Malay and Baba May, the use of Hokkien first personal pronoun $g u a \sim w a$ 我 and the second personal pronoun $l u$ 汝 can be observed (see also Lee 2014: 396). While the direct use of these personal pronouns is restricted to Baba Malay according to Pakir (1986: 106), my study demonstrates otherwise. ${ }^{9}$ It is not uncommon in the marketplace to hear an Indian man address a Chinese shopkeeper with lu 'you' and refer to himself as wa 'I'. Although the use of Malay awak 'you' and saya 'I' often marked the beginning of such conversations, lu 'you' and wa 'I' quickly became the norm as they went on. This widespread phenomenon substantiates the status of gua $\sim w a$ and $l u$ as part of the Bazaar Malay lexicon. Table 4.1 illustrates Hokkien influence on Bazaar Malay and Baba Malay personal pronouns.

8 Presumably from Hokkien chiá-hu 姐夫 (Gwee 20o6: 54).

9 Both are also common in Jakarta Indonesian (Adelaar 1991: 26), whereas $l u$ as a 2 SG is also observed in Kupang Malay (Paauw 2008: 166, 463). 
TABLE 4.1 Personal pronouns in Malay, Hokkien, Baba Malay, and Bazaar Malay

\begin{tabular}{|c|c|c|c|c|c|c|}
\hline \multirow[t]{2}{*}{ Language } & \multicolumn{2}{|c|}{ First person } & \multicolumn{2}{|c|}{ Second person } & \multicolumn{2}{|c|}{ Third person } \\
\hline & Singular & Plural & Singular & Plural & Singular & Plural \\
\hline Malay & $\begin{array}{l}\text { saya, } \\
\text { aku }\end{array}$ & $\begin{array}{l}\text { kita (INC), } \\
\text { kami (EXC) }\end{array}$ & $\begin{array}{l}\text { awak, } \\
\text { kamu, } \\
\text { kau, } \\
\text { anda }\end{array}$ & $\begin{array}{l}\text { awak, } \\
\text { semua }\end{array}$ & dia $\sim$ ia & mereka \\
\hline Hokkien & $\begin{array}{l}\text { gua } \\
\text { wa 我 }\end{array}$ & $\begin{array}{l}\text { lan 咱 }(\text { INC), } \\
\text { gun } \sim \text { guan } \\
\text { 阮 }(\text { EXC) }\end{array}$ & lu, li 汝 & lin 恁 & $\mathrm{i}$ 伊 & $\begin{array}{l}\text { in 栶, } \\
\text { i-lang } \\
\text { i nang } \\
\text { 伊儂 }\end{array}$ \\
\hline Baba Malay & $\begin{array}{l}\text { saya, } \\
\text { gua }\end{array}$ & kita & lu & luorang & dia & diaorang \\
\hline $\begin{array}{l}\text { Bazaar } \\
\text { Malay }\end{array}$ & $\begin{array}{l}\text { saya, } \\
\text { aku, wa }\end{array}$ & $\begin{array}{l}\text { kitaorang, } \\
\text { kita }\end{array}$ & awak, lu & luorang & dia & $\begin{array}{l}\text { diaorang } \\
\sim \text { diorang }\end{array}$ \\
\hline
\end{tabular}

ADAPTED FROM PAKIR (1986), LEE (2014: 30), AND AYE (2006: 72)

Note that the use of gua is considered impolite by Malays and even by some Chinese in my Bazaar Malay study. In the novel Si Hitam Yang Chantek, the perception of gua as rude is reflected in its frequency of occurrence - gua 49 times vs. and saya 2522 times - although it may also be due to the social status of Black Beauty, with its narrator horse as the protagonist. Yet, as commented by my participants, the direct adoption of Hokkien pronouns in Bazaar Malay manifests a close affinity between interlocutors of different ethnicities.

\subsection{Temporal Expressions}

In Baba Malay, temporal expressions of Hokkien origins are related to culture and in particular the days of special occasions marked by the lunar calendar. Lee (2014) lists ten Hokkien words indicating such days, including chay-it 初一 'the new year's day' and chap-gor 十五 'the fifteenth day of lunar month'. I did not detect any such terms in my Bazaar Malay data, as these Hokkien terms portray a specific Peranakan Chinese identity.

\subsection{Business Terms}

Some Bazaar Malay terms dealing with business are Hokkien words. My data show two such terms: kongsi 公司 'a company or firm; to share' and tau ke 頭家 
'a well-to-do Chinese; an employer; the head of the business.' ${ }^{10}$ Nine instances of tau ke were also observed in the Baba Malay novel (Chapter 38). See below for an example:

2) Tapi betul ada juga tauke-tauke
but true have also
kepada kita orang ...

'But, it is true that there are also employers who are kind to us'.

With reference to the term tauke, Pakir (1986:114) considers Malay as the source of this term. However, I would argue that it comes from Hokkien, even though it is now part of the Malay lexicon. In Hokkien, the term tauke, which literally means 'first family', is a compound made up of tau 頭 'head' and ke 家 'family'. It is also used among Hokkien speakers as well as non-Chinese Burmese in Myanmar, where Malay is not spoken.

\subsection{Culinary Terms}

Hokkien terms for cooking ingredients and dishes identified in Bazaar Malay include cincau 清草 'grass-jelly', mi 麵 'yellow noodles', mihun 麵粉 'rice vermicelli', twahun 大粉 'bigger rice vermicelli', mi siam 米暹 'sweet-and-sour noodles', popiah 薄餅 'spring rolls', tau cio 豆醬 'preserved soy beans', tauge 豆 芽 'bean sprouts', taukwan 豆乾 'bean curd', and tauyu 豆油 'soy sauce'. This list mostly comes from a consultant who was preparing food in her kitchen while explaining to me how to do so. Hokkien words and phrases in this category are not exhaustive and there are many more of them in Bazaar Malay. These words are also found in Baba Malay. The following is an example from Si Hitam Yang Chantek (Chapter 44):

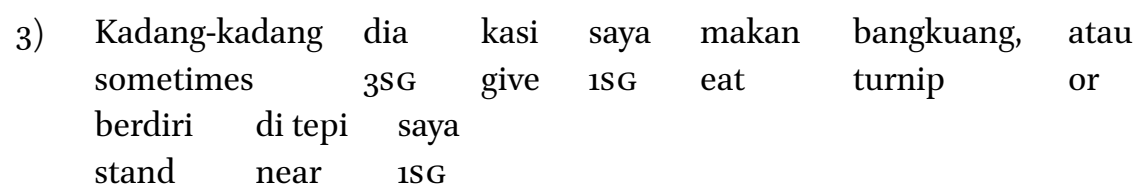

'Sometimes, he fed me turnip or stood near me.'

Note that the word bangkuang is also observed in Lee's data (2014), where its origin is indicated as Hokkien. Two points merit our attention: the referent of bangkuang (or mangkuang), and the question of its etymological origins.

10 The meanings of kongsi and tau ke are as given in Pakir (1986: 114). 
Though it is glossed as 'turnip', following Lee (2014), a more appropriate gloss would be 'jicama (Pachyrhizus erosus)' - also known as 'sweet turnip' or 'Chinese turnip' - which is one of the ingredients of Hokkien popiah 薄餅 (see also malaysiavegetarianfood.com). Some people argue it is of Malay origin, which I do not believe to be accurate. In Standard Malay, the product is referred to as ubi sengkuang, not bangkuang. Lee (2014: 471) also lists it as a Hokkien word. In Burmese Hokkien, turnip is tuar tau chai 大頭菜, jicama is kua jiu 芥薯, and sweet potato is han jiu 番薯. The jicama is known as tau aw jiu 豆仔薯 in Taiwanese Hokkien, whereas in Singapore, sa koh 沙葛 and bangkuang 芒光 are common names. Hence, the word bangkuang strikes me as a Hokkien loanword unique to the Malay-speaking regions.

As these Hokkien-derived culinary terms can be heard in multiple contexts in Singapore, it is logical to conclude that they are part of the common core of the Singaporean linguistic repertoire, regardless of ethnic backgrounds. The same process is observed in Singapore Colloquial English. As these terms are also observed in other colloquial varieties of Malay, Pakir (1986) views them as Malay components which may have entered Baba Malay via Malay. As loanwords from different languages have been adopted into Malay via religion - such as Arabic words through Islam and Sanskrit words through Hinduism and Buddhism - the existence of Hokkien loanwords in generic Malay, as argued by Pakir (1986), is not unique to Baba Malay. Yet I agree with Ansaldo and Mathews (1999: 50) that these words may well have "entered [their emphasis] Malay through Hokkien speakers shifting to Malay and subsequently spread" to other Malay dialects, as there have been contacts between China and Southeast Asia through envoy, Buddhist pilgrims, and traders and this is hardly a recent phenomenon (Tan 1988: 28). Rather than being the recipient, we may therefore envision Baba Malay as the donor of these words.

\section{Loan Shifts, Loan Translations, and Loan Blends}

In what follows, I will pay attention to three common manifestations of language contact and lexical borrowing - loan shifts, loan translations, and loan blends - providing examples in each category of Hokkien influence on the two Malay varieties being researched here.

\subsection{Loan Shifts}

As discussed previously, some Malay-derived words in Baba Malay display non-mainstream meanings. One prominent example is found in the religious 
sphere. In contemporary Malay, a number of religious terms have been claimed as the prerogative of specific ethno-religious groups. For example, the term Allah - derived from Arabic - was ruled in 2013 as a Muslim-only word by a Malaysian Court, inviting criticism from "Muslim thinkers and groups around the world" (Mandal 2016: 390; see also Leow 2016: 218-19). In multicultural, multilinguistic, and multi-ethnic countries like Singapore or Malaysia, the legal restriction of words to certain groups is untenable on a linguistic level, among many things, due to the aforementioned proclivity towards loan shifts, which commonly emerge from contact situations. We recall here that a loan shift refers to the adaptation of a word from the lexifier language, in this case Malay, to a shifted meaning. Thus, in the novel Si Hitam Yang Cantek, intended for the Christian Peranakan community, 'God' is referred to as Tuhan Allah (21 times) and Allah (4 times), compared its more neutral equivalent Tuhan (1 time). The higher frequency of Tuhan Allah or Allah substantiates that Christians commonly used this word. However, no such usage was found in this study's Bazaar Malay data, presumably because of its use in limited contexts.

\subsection{Loan Translations}

Loan translations or calques, which are analysed by Lefebvre (1998) through the prism of relexification, can be observed in the pluralization of the second and third personal pronouns and the formation of possessive pronouns. This process encompasses copying Hokkien semantic and morphosyntactic properties and relabelling them in Malay. Calques like these are commonly observed in contact situations (Sebba 1997: 92, 119).

Both in Baba Malay and Bazaar Malay, the plural forms of the personal pronouns are formed by adding orang 'person; people' to the respective pronouns:

$\begin{array}{ll}\text { SG } & + \text { orang 'person' } \\ \text { lu } & \text { luorang 'you (PL)' } \\ \text { dia } & \text { diaorang 'they' }\end{array}$

Generic Malay exhibits personal pronouns with special plural forms, e.g. kita (1PL.INC) or kami (1PL.EXL) 'we' and mereka (3PL) 'they'. Yet in Si Hitam yang Chantek, 344 instances of diaorang 'they' and no single instance of the Malay merek $a$ were found.

Plural forms in Hokkien, by contrast, are derived by adding lang nang 儂 'person; people' or its contracted form $-n$ immediately after the respective pronouns (Bodman 1955: 82; Ansaldo \& Matthews 1999: 31): 
SG

gua 我 'I'

li 汝 'you (SG)'

$i$ 伊 's/he'
+ lang $\sim$ nang / - $\boldsymbol{n}$ 'person'

guan $\sim$ gun 阮 'we (EXC)'

lin 恁 'you (PL)'

in 栶 / i-lang i-nang 伊儂 'they'

It follows from this that the Hokkien use of lang / $-n$ 'person' as plural marker was relabelled in Bazaar Malay and Baba Malay - using the inherited noun orang 'person; people' - and added to singular pronouns to derive their plural forms. The outcomes of this relexification process or calque of Hokkien plural pronouns include the pronouns diaorang 'they' and luorang 'you (PL)'. Bazaar Malay, Baba Malay, and Hokkien thus share the use of a noun - orang (Malay) or lang nang / $-n$ (Hokkien) - as pronominal plural marker. According to Paauw (2008: 170), the use of orang (or its variants) as plural marker is also observed in a number of eastern Indonesian contact varieties: Manado Malay (except in the 2PL), Ambon Malay, Banda Malay, North Moluccan Malay (except in the 2PL), Kupang Malay, Larantuka Malay, and Papua Malay (except in the 2PL).

Loan translations are also observed in possessive constructions. In generic Malay, possession is formed syntactically, by placing the respective noun or pronoun after the head noun (the possessed item). For example, buku Nora 'Nora's book' or rumah saya 'my house'. The third person pronouns dia 's/he' and mereka 'they' have a different form (-nya) to indicate possessives, e.g. rumahnya 'his/her/their house'. In Bazaar Malay and Baba Malay, conversely, possession is expressed through the Malay word punya 'to possess' after the respective pronouns or nouns. Consider the following examples from, respectively, Baba Malay taken from the second chapter of Si Hitam Yang Chantek - in which 782 instances of such use were observed - and Bazaar Malay:

$\begin{array}{llllll}\text { 4) Saya } & \text { keluarkan } & \text { semua } & \text { saya } & \text { punya } & \text { kekuatan } \\ \text { 1SG } & \text { exert } & \text { all } & \text { ISG } & \text { punya } & \text { strength }\end{array}$

'I exerted all my strength'

$\begin{array}{llllll}\text { 5) Dia } & \text { kasi } & \text { dia } & \text { punya } & \text { kawan } & \text { hantar. } \\ \text { 3SG } & \text { CAU } & \text { 3SG } & \text { punya } & \text { friend } & \text { send } \\ \text { 'She let her friend send (it)'. (Bazaar Malay Informant G) } & \end{array}$

The following juxtaposition demonstrates clearly how this construction is copied from Hokkien, whereby the Hokkien particle $e$ 的 is added immediately after the possessor noun or pronoun and replaced with the Malay word punya 'possess' in the two contact languages: 


$\begin{array}{lll} & \text { PRON } & + \text { POss } \\ \text { Hokkien } & i \text { 伊 's/he' } & i e \text { 伊的 'his; her' } \\ \text { Bazaar Malay, Baba Malay } & \text { dia 's/he' } & \text { dia punya 'his; her' }\end{array}$

The same phenomenon, that is, the use of the possessive marker punya or its variants, is observed in the contact varieties of eastern Indonesia (Paauw (2008: 174)): pe in Manado Malay and North Moluccan Malay, pung or pong in Ambon Malay, pung or pu in Banda Malay, pung in Kupang Malay, puN in Larantuka Malay, and punya or $p u$ in Papua Malay. Together with the second person pronoun $l u$ in Kupang Malay stated earlier, this suggests an eastward influence ultimately exerted by Hokkien.

Temporal expressions in Bazaar Malay and Baba Malay also demonstrate the relexification of Hokkien. To name the days of the week, both Baba Malay and Bazaar Malay use the combination of the noun hari or ari 'day' and a number. Although these designations consist of Malay words, they are arranged in a way that reflects a Hokkien pattern. The naming system for the days of the week in generic Malay, Bazaar Malay, Baba Malay, and Hokkien is illustrated in Table 4.2.

While Pakir (1986: 113) suggests that this naming system in Baba Malay is an outcome of Malay lexification, I see it as another instance of lexical calquing, with Hokkien entries being replaced by Malay parallels. The generic Malay naming system is itself derived from Arabic numerals, Isnin 'two', Selasa 'three', etc., but with a different numbering. For example, while Monday is referred to as 'Day 1' in Baba Malay and Bazaar Malay, it is referred to as 'Day 2' (Hari Isnin) in Standard Malay. While the use of numerals to refer to the weekdays

TABLE 4.2 Expressions for the days of the week in the languages concerned

\begin{tabular}{lllll}
\hline $\begin{array}{l}\text { Generic } \\
\text { Malay }\end{array}$ & $\begin{array}{l}\text { Bazaar } \\
\text { Malay }\end{array}$ & Baba Malay & Hokkien & $\begin{array}{l}\text { English } \\
\text { gloss }\end{array}$ \\
\hline Hari Isnin & (h)ari satu & (h)ari satu & pai-it 拜一 & Monday \\
Hari Selasa & pai-zi 拜二 & Tuesday \\
Hari Rabu & (h)ari tiga & pai-sa 拜三 & Wednesday \\
Hari Khamis & (h)ari empat & pai-si 拜四 & Thursday \\
Hari Jumaat & (h)ari lima & (h)ari lima & pai-go 拜五 & Friday \\
Hari Sabtu & (h)ari enam & (h)ari enam & pai-lak拜六 & Saturday \\
Hari Ahad / & (h)ari tujuh / & (h)ari minggu & pai-chit 拜七/ & Sunday \\
Minggu & minggu & & lei-pai 禮拜 & \\
\hline
\end{tabular}

BASED ON PAKIR (1986), LEE (2014: 403), AND AYE (2006) 
is common cross-linguistically, the Sinitic system was adopted in Baba Malay and Bazaar Malay. Following the Hokkien morphosyntactic property whereby the noun pai 拜 'day' is followed by the number of the specific day in the week, Bazaar Malay and Baba Malay thus replaced these Hokkien words with their Malay counterparts: hari ari 'day' followed by a number. As noted by Lee (2014), the names of the months in Baba Malay likewise follow the Hokkien structure replaced with the corresponding Malay lexical items, as in bulan satu 'January' (lit. 'month one').

$\begin{array}{ll}\text { Bazaar Malay, Baba Malay } & \begin{array}{l}\text { hari satu 'Monday' } \\ \text { day one } \\ \text { pai-it } \text { 拜一 'Monday' } \\ \text { day-one }\end{array}\end{array}$

See below for an example from Si Hitam Yang Chantek (Chapter 43):

6) Dan pada hariminggu saya tak kerja, dan bila harisatu
and on Sunday
datang saya not work and when Monday
come segar.

'And on Sunday, I do not work, and when Monday comes I feel fresh.'

It is not uncommon to hear the same naming system used by ethnic Malays in informal contexts. More research is needed to investigate whether this is a feature of informal Malay, which tends to be semantically more transparent than standard Malay, or the result of influence from Bazaar Malay as a historical lingua franca.

\subsection{Loan Blends}

A loan blend is a hybridization of foreign and native elements. Examples of loan blends in English, as given by Tseng (2004: 170), include 'chopstick', where chop is a Chinese Pidgin English word; 'hoisin sauce', where hoisin 海鮮 is Chinese; and 'kung pao chicken', where kung pao 宮保 is a Chinese element. Though this type of loan blend was not observed in my more formal Bazaar Malay data, I have noticed its usage in informal conversations with older shopkeepers in the wet market.

In Baba Malay, out of the 72 kinship terms listed by Lee (2014: 399-402), we find ten loan blends which combine a Hokkien kinship term followed by a Malay noun or cardinal number indicating the seniority of the particular 
relative. Examples include tachi besar 'eldest sister' (lit. elder.sister big) and hia numbor dua 'second elder brother' (lit. elder.brother number two), containing the Hokkien words tachi 大姐 and hia 兄. Some other expressions include ati it gor it chap 'nervous', where the Malay word ati 'heart' is blended with the Hokkien words it gor it chap 一五一十 'one five, one ten', and buat suay 'to cause misfortune' (lit. to make misfortune), where the Malay word buat 'to make' is blended with the Hokkien word suay 衰 'misfortune'.

\section{$6 \quad$ Concluding Remarks}

This chapter has highlighted two aspects relating to the role of Hokkien in the lexicon of Bazaar Malay and Baba Malay. The first is the extent of Hokkien influence on Bazaar Malay in comparison to Baba Malay, and the second the nature of Hokkien lexical influence in Bazaar Malay from the perspective of Pidgin and Creole Linguistics. Out of the four options of borrowing I have discussed, most instances involve the direct use of Hokkien words and loan translations, which can be observed in both varieties. Limited examples of loan shifts and loan blends occur in Baba Malay, but not in Bazaar Malay.

The influence of Hokkien on the lexicon of these two contact varieties is both overt and covert. Compared with Baba Malay, its lexical impact on Bazaar Malay is minimal. Bazaar Malay retains a small number of overt lexical items from Hokkien which can be categorized into four groups (compared to twelve groups attested in Baba Malay) that are clustered around cultural domains. Even in these four categories, there are fewer Hokkien words in Bazaar Malay than in Baba Malay.

This can be explained by two factors: a sense of community and of Baba Chinese identity. Baba Malay speakers belong to a distinct speech community and constitute a culturally identifiable group, historically different from China-born immigrants. Contrary to this, Bazaar Malay has never existed as a (native) speech community. Besides, as it is spoken by non-Malays of Chinese parentage but also other ethnic groups, we cannot expect the same degree of Hokkien lexical retention seen in Baba Malay. In the latter, lexical items closely tied with the Hokkien Chinese culture, customs, emotions, and ethnic value judgments have been handed down as cultural heritage by the ancestors of today's Baba Malay, although nowadays they do not typically speak Hokkien or any other regional Sinitic varieties anymore (see also Tan 1988: 120). These lexical items, which do not exist in Bazaar Malay, in fact mark the unique identity of the Baba Chinese as opposed to non-Baba Chinese. The survival of such 
lexical items in their language can thus be accounted for by their persistence to maintain the Baba Chinese identity and their sense of belonging to the associated speech community.

In comparison with other pidgins and creole languages, the degree of influence from Hokkien in Bazaar Malay is remarkably significant. Since the speakers of substrate languages tend to be stigmatized in contact situations, as argued by Bao (2003), borrowing from the substrate is rare or minimal crosslinguistically. The presence of Hokkien words in Bazaar Malay confirms that Hokkien speakers were not historically stigmatized, given their social and economic dominance in the region. In this regard, the significant role of Hokkien in Bazaar Malay exemplifies an unusual scenario of language contact, in which the substrate language and its speakers receive a better treatment than is usually the case.

As a final point, we may recall that typical creoles are developed in a contact situation involving two groups with unequal power. The presence and nature of Hokkien loanwords in Baba Malay have led me to agree with Ansaldo et al. (2007) and Lee (2014: 22), namely, that Baba Malay was born out of intermarriage between ethnicities of relatively equal power. This linguistic finding has broader implications for historical scholarship on the Malay-speaking world and invites comparisons elsewhere in Southeast Asia.

\section{References}

Adelaar, K. Alexander, 'Some notes on the origin of Sri Lanka Malay', in H. Steinhauer (ed.) Papers in Austronesian Linguistics No. 1 (Canberra: Department of Linguistics, Research School of Pacific Studies, 1991): 23-37.

Adelaar, K. Alexander and Prentice, D.J., 'Malay: Its history, role and spread', in Stephen A. Wurm, Peter Mühlhäusler and Darell T. Tryon S. (eds.) Atlas of languages of intercultural communication in Pacific, Asia and the Americas, Volume II $/ 1$ (Trends in Linguistic Documentations 13, Berlin: Mouton de Gruyter, 1996): 6736-93.

Ansaldo, Umberto and Matthews, Stephen, 'The Minnan substrate and creolization in Baba Malay', Journal of Chinese Linguistics 27/1 (1999): 37-68.

Ansaldo, Umberto, Lisa Lim, and Salikoko S. Mufwene, "The sociolinguistic history of the Peranakans: What it tells us about "creolization", in U. Ansaldo, S. Matthews and L. Lim (eds.), Deconstructing Creole (Amsterdam:John Benjamins, 2007): 203-26.

Aye, Khin Khin, Bazaar Malay: history, grammar and contact (unpublished PhD thesis, National University of Singapore, 2006).

Aye, Khin Khin, 'Singapore Bazaar Malay', in Susanne Michaelis, Philippe Maurer,

Martin Haspelmath, and Magnus Huber (eds.) The survey of pidgin and creole 
languages Volume III: contact languages based on languages from Africa, Australia, and the Americas (Oxford: Oxford University Press, 2013): 86-93.

Bakker, Peter, 'Bazaar Malay \& Baba Malay: Is There a Connection?', Paper presented at the SPCL Conference at the 2004 LSA Meeting (Boston, Massachusetts, 2004).

Bao Zhiming, 'Social stigma and grammatical autonomy in nonnative varieties of English', Language in Society, 32 (2003): 23-46.

Bao Zhiming, 'The aspectual system of Singapore English and the systemic substratist explanation', Journal of Linguistics 41/2 (2005): 237-67.

Bao, Z.M., 'The systemic nature of substratum transfer', in Markku Filppula, Juhani Klemola and Devyani Sharma (eds.), The Oxford Handbook of World Englishes (Oxford: Oxford University Press, 2015): 621-38.

Baxter, A.N., A description of Papia Kristang (Malacca Creole Portuguese). (PhD thesis, Australian National University, Canberra, 1985).

Bodman, Nicholas C., Spoken Amoy Hokkien (2 vols, Kuala Lumpur: Charles Grenier and Company, 1955).

Collins, J.T., 'Malaysian and Bazaar Malay: polarity, continuity and communication', in Asmah Haji Omar (ed.), National language and communication in multilingual societies (Kuala Lumpur: Dewan Bahasa dan Pustaka, 1987): 151-74.

Collins, J.T., Malay, world language: A short history (2nd edn., Kuala Lumpur: Dewan Bahasa dan Pustaka, 1998).

Durkin, Phillip, Borrowed words: A history of loanwords in English (Oxford: Oxford University Press, 2014).

Egerod, S., 'A Note on Some Chinese Numerals as Loan Words in Tai'. Second Series, 47/1-2 (1959): 67-74.

Freedman, Maurice, 'Immigrants and associations: Chinese in the 19th Century Singapore', Comparative Studies in Society and History 3 (1960): $25^{-48}$.

Gil, David, 'Escaping Eurocentrism: Fieldwork as a process of unlearning', in Paul Newman and Martha Ratliff (eds.), Linguistic fieldwork (Cambridge: Cambridge University Press, 2001): 102-32.

Gwee, Willian Thian Hock, Mas sepuloh: Baba conversational gems (Singapore: Armour Press, 1993).

Gwee, Willian Thian Hock, A Baba Malay dictionary: The first comprehensive compendium of Straits Chinese terms and expressions (Singapore: Armour Press, 2006).

Hall, K.R., 'The opening of the Malay world to European trade in the sixteenth century', Journal of the Malaysian Branch of the Royal Asiatic Society (1985): 85-104.

Hay, J., 'Chinese in Southeast Asia', Facts and Details, 2008. Retrieved 30 June 2008 from http://factsanddetails.com/asian/cat66/sub418/item2729.html.

Hockett, C.F. (ed.), The life and growth of language (New York: Dover Publication, 1979). Hoffer, B.L., 'Language borrowing and the indices of adaptability and receptivity', Intercultural Communication Studies, XIV/2 (2005): 53-72. 
Holm, John, Pidgins and creoles, vol. 1 (Cambridge: Cambridge University Press, 1989). Hoogervorst, Tom G., 'What kind of language was "Chinese Malay" in late colonial Java?', Indonesia and the Malay World, 45/133 (2016): 294-314.

Jones, Russel, Chinese Loan-Words in Malay and Indonesian: A Background Study (Kuala Lumpur: University of Malaya, 2009).

Kuo, Eddie Chen-Yu, 'A sociolinguistic profile of Singapore', Sociology Working Paper No. $5^{2}$ (Singapore: Chopmen Enterprises, 1976).

Lee, Nala Huiying, A grammar of Baba Malay with Sociophonetic considerations (unpublished PhD thesis, The University of Hawaii, 2014).

Lefebvre, Claire, Creole genesis and the acquisition of grammar: The case of Haitian creole (Cambridge: Cambridge University Press, 1998).

Lefebvre, Claire and Lumsden, John, 'Le role central de la relexification dans la genèse de langues creoles', Plurilinguismes 8 (1994a): 47-93.

Lefebvre, Claire and Lumsden, John, 'Relexification in creole genesis', in Claire Lefebvre and John Lumsden (eds.), The central role of relexification in creole genesis: The case of Haitian creole (research report prepared for ss HRCC on the project La genèse $d u$ créole haïtien: un cas particulier d'investigation sur la forme de la grammaire universelle, Université du Québec à Montréal, 1994b).

Leow, Rachel, Taming Babel: Language in the Making of Malaysia (Cambridge: Cambridge University Press, 2016).

Ling Pyau, 'Causes of Chinese Emigration', The Annals of the American Academy of Political and Social Science, 39 (1912): 74-82.

Lockard, Craig A., 'Chinese migration and settlement in Southeast Asia before 1850: Making fields from the sea', History Compass 11/9 (2013): $765^{-81}$.

Mandal, Sumit, 'Cultural Geographies of the Malay World: Textual Trajectories in the Indian Ocean', Philological Encounters, 1 (2016): 370-95.

Milroy, Lesley and Gordon, Matthew, Sociolinguistics: Method and interpretation (Malden, MA: Blackwell, 2003).

Minde, D. van, Malayu Ambon: Phonology, morphology, syntax (Leiden: Research School CNWS, 1997).

Mithun, Marcyliena, 'Who shapes the record: The speaker and the linguist?' in Paul Newman and Martha Ratliff (eds.), Linguistic fieldwork (Cambridge: Cambridge University Press, 2001): 34-44.

Muysken, Pieter, 'Half-way between Quenchua and Spanish: The case for relexification', in Arthur R. Highfield and Albert Valdman (eds.), Historicity and variation in Creole Studies (Ann Arbor, MI: Karoma, 1981): 52-79.

Ng, Kim Chew, 'Sinophone/Chinese: "The South where Language is lost" and Reinvented, translated by Brian Bernards', in Shu-mei Shih, Chien-hsin Tsai, and Brian Bernards (eds.) Sinophone Studies: A Critical Reader (New York: Columbia University Press, 2013), 74-92. 
Paauw, Scott, The Malay contact varieties of eastern Indonesia (unpublished $\mathrm{PhD}$ thesis, State University of New York, 2008).

Pakir, Anne, 'Lexification and idiomaticity in Baba Malay, the language of the Straits Chinese', Working Papers in Linguistics (Honolulu: University of Hawaii, Department of Linguistics), 16/2 (1984): 63-85.

Pakir, Anne, A linguistic investigation of Baba Malay (unpublished PhD thesis, University of Hawaii, 1986).

Pan, Lynn, Sons of the Yellow Emperor: A history of the Chinese diaspora (Boston, MA: Little, Brown, 1990).

Platt, John and Weber, Heidi, English in Singapore and Malaysia: Status, features, functions (Oxford: Oxford University Press, 1980).

Poedjosoedarmo, Gloria R., 'What is happening to Malay in Singapore?', in Cecilia Odé and Wim Stokhof (eds.), Proceedings of the Seventh International Conference on Austronesian Linguistics (Amsterdam: Rodopi, 1997): 73-84.

Population Trends, 'Department of Statistics, Ministry of Trade and Industry, Republic of Singapore', 2017.

Poston, D.L. Jr., 'Overseas Chinese', in Demeny P. and McNicoll G. (eds.) Encyclopedia of Population (New York, NY: Macmillan Reference USA, 2003).

Poston, D.L. Jr. and Luo, H., 'Chinese student and labour migration to the United States: Trends and policies since the 1980s', Asian and Pacific Migration Journal, 16/3 (2007): 323-55.

Poston, D.L. Jr. and Wong, Juyin Helen, 'The Chinese diaspora: The current distribution of the overseas Chinese population', Chinese Journal of Sociology, 2/3 (2016):348-73.

Pou, Saveros and Jenner, Philip N., 'Some Chinese loanwords in Khmer', Journal of Oriental studies (1973): 1-9o.

Prentice, D.J., 'The best chosen language', Hemisphere, 22/3 (1978): 18-23.

Prentice, D.J., 'Malay and Indonesia', in William Bright (ed.), International encyclopedia of linguistics (Oxford: Oxford University Press, 1992): 374-80.

Proudfoot, I., Early Malay printed books: A provisional account of materials published in the Singapore-Malaysia up to 1920, noting holdings in major public collections (Kuala Lumpur: University of Malaya, 1993).

Purcell, Victor, The Chinese in Malaya (Oxford: Oxford University Press, 1948).

Sebba, Mark, Contact languages: pidgin and creole languages (New York: St. Martin's Press, 1997).

Shellabear, W.G., 'Christian Literature for Malaysia: I. Races and Languages', The Moslem World, IX/4 (1913): 379-84.

Tadmor, Uri, 'Loanwords in the world language: findings and results', in Martin Haspelmath and Uri Tadmor (eds.), Loanwords in the world languages: A comparative handbook (De Gruyter Mouton: Berlin, 2009): 36-55. 
Tan Chee Beng, The Baba of Melaka: culture and identity of a Chinese Peranakan community in Malaysia (Selangor: Pelanduk Publications, 1988).

Tan Chee-Beng, Chinese overseas: comparative cultural issues (Hong Kong: Hong Kong University Press, 2004).

Tarling, Nicholas, Singapore and the Singaporeans since 1819 (Auckland: University of Auckland, 1992).

Thurgood, Elzbieta A., A description of Nineteenth Century Baba Malay: A Malay variety influenced by language shift (PhD thesis, University of Hawaii. Ann Arbor, 1998).

Tseng, Hugo T.Y., 'Rendering Chinese-culture specific vocabulary into English Predicaments and prospects', in Chan Sin-Wai (ed.), Translation and Bilingual Dictionaries (Tübingen: Niemeyer Max Verlag GmbH, 2004).

Vaughan, Jonas Daniel, Manners and customs of the Chinese of the Straits Settlements (Kuala Lumpur: Oxford University Press, 1971).

Wang, Anyi, 'The Fate of Language (Parts 1 and 2)', Xingzhou ribao, xingyun ban [Sin Chew daily starcloud supplement] (13 July and 7 December 1993).

Wang, Gungwu, China and the Chinese overseas (Singapore: Times Academic Press, 1991).

Yoong, S.K. and Zainab, A.N., 'Chinese literary works translated into Baba Malay: A bibliometric study', Malaysian Journal od Library \& Information Science, 7/2 (2002): 1-23. 